\title{
THE STRUGGLE TO REFORM THE ROYAL COLLEGE OF PHYSICIANS, 1767-1771: A SOCIOLOGICAL ANALYSIS
}

by

\author{
IVAN WADDINGTON
}

THE HISTORY of the medical profession in the first half of the nineteenth century is, to a considerable extent, the history of the movement for medical reform. In the course of the development of this movement, a large and growing section of the profession put forward demands for the democratic reform of the medical corporations, for changes in the laws relating to medical practice, and for the reform of medical education. However, the nineteenth-century campaign for medical reform, which eventually resulted in the passage of the Medical Act of 1858, had its social origins in changes in the structure of the profession which were already well under way in the eighteenth century. In this paper, an attempt will be made to outline one of the earlier, and relatively neglected, struggles for reform - that which centred on the Royal College of Physicians in the years 1767-71-and to provide an analysis of the social basis of this struggle. Before this can be done, however, it is necessary to examine briefly the institutional structure of the medical profession during this period.

In the eighteenth century, the law recognized only three types of medical practitioners: physicians, surgeons, and apothecaries. These three groups were organized in a hierarchical structure, with physicians forming the 'first class of medical practitioner in rank and legal pre-eminence'. ${ }^{1}$ By the statute of 32 Henry 8 physicians were allowed to practise physic in all its branches, among which surgery was included. However the disdain which physicians, as a body of learned men, felt for manual work, had led to a contraction in their duties. By the eighteenth century, the practice of the physician was held to be properly confined to prescribing of drugs to be compounded by the apothecary, and in superintending operations performed by surgeons in order to prescribe what was necessary to the general health of the patient, or to counteract any internal disease.

The controlling body for physicians was the Royal College of Physicians in London. Established by charter in 1518, the powers of the College were confirmed by an Act of 1522. By this Act, no persons, excepting graduates of Oxford or Cambridge, were allowed to practise physic unless examined and approved by the College. In the course of the development of the College, a distinction had grown up between the

1 J. W. Willcock: The Laws Relating to the Medical Profession, London, 1830, p. 30. The outline of the legal status of physicians and surgeons is based on the work of Willcock, who was an authority on these matters. At the time Willcock wrote, the legal status of physicians and surgeons was much the same as it had been in the mid-eighteenth century, with the exception that both groups were, at the later date, subject to the operation of the Apothecaries Act of 1815. 


\section{Waddington}

fellows on the one hand, and the licentiates on the other. ${ }^{2}$ The licentiates simply held a licence to practise medicine in London, and in an area seven miles around London. They were not allowed to take part in the formulation of College policy, nor were they allowed to vote at elections. All political offices and all decision-making functions within the College were monopolized by the fellows, almost all of whom were graduates of Oxford or Cambridge. ${ }^{3}$

In sharp contrast to physicians, surgeons were regarded as craftsmen rather than gentlemen. The surgeons had been united with the barbers in the Company of BarberSurgeons until 1745, in which year they formed a separate organization, the Company of Surgeons. The proper sphere of practice of the surgeon was held to consist generally in the cure of all outward diseases, and in the use of surgical instruments in all cases where this was necessary. ${ }^{4}$

The lowest order of the medical profession, the apothecaries, had been organized in the Society of Apothecaries since 1617. The charter of the Society required seven years' apprenticeship to a member as an essential qualification for admission to the freedom of the company, and stated that at the end of seven years 'every such apprentice .... shall be examined, proved, and tried concerning the preparing, dispensing, handling, commixing and compounding of medicines.'5 However by the early part of the eighteenth century, the apothecaries had successfully grafted medical on to pharmaceutical practice, and had won legal recognition of their right to do so. Thus apothecaries were able to prescribe, as well as to dispense medicines, though they were entitled to charge only for medicines supplied, not for attendance or advice. $^{6}$

This traditional tripartite structure of the profession constituted what may be called an estate system of stratification. Thus the 'orders' of the profession were hierarchically ranked, and each grade of practitioner had privileges which were legally defined. The general concept of the qualified or registered practitioner had no place in English law prior to the Medical Act of 1858; instead there were separate laws relating to physicians, to surgeons, and to apothecaries. This brief outline of the structure of the profession is necessary for it will be suggested that the social origins of the reform movement within the College of Physicians in the period 1767-71 are to be found in the emergence of a new type of practitioner who cut across all these professional divisions which were enshrined not only in the legal system, but in the institutional structure of the profession as a whole.

The struggle to reform the College of Physicians was sparked off by an incident

There was also a third group, the extra-licentiates, who held a licence to practise medicine in England and Wales, excluding the London area. Like the licentiates, they took no part in formulating College policy, and could not vote at elections. They appear not to have been involved in the movement to reform the College.

In the period 1700-1770, the College admitted 148 fellows. Of this number, 140 held medical degrees from, or had incorporated at, Oxford or Cambridge. Of the others, six had graduated from contintental universities, and two from Scottish universities. See Munk's Roll, vol. II.

- This is a very general outline of what was a very complex legal situation. For a more detailed examination of the legal status of the surgeon, see Willcock, op. cit., pp. 56-58.

'Quoted in Rachel E. Franklin, 'Medical Education and the Rise of the General Practitioner', Ph.D. Thesis, University of Birmingham, 1950, p. 112.

- It was not until 1829 that apothecaries won the right to charge for advice, and not until the following year that they were entitled to charge for both advice and medicines supplied. See Towne v. Gresley, 3C and P.581, and Handey v. Henson, 4 Car. and P.110. 
involving an obstetrician named Dr. Letch, who had been summoned to be examined as a licentiate. After the examination, however, a muddle occurred when the President took the votes. One of the examiners said that his vote had been counted in Dr. Letch's favour when really it was on the other side, and if it had been correctly counted the doctor would not have passed. The special general comitia of the College upheld the rejection of Dr. Letch, but in the meantime Dr. Letch had gone to law. The court of king's bench sent down a rule for the College to show cause why it should not admit Dr. Letch a member. Before the matter came into court, the licentiates had formed themselves into the Society of Collegiate Physicians. Fellows were not to be admitted to its membership and the Society's main aim was to campaign for a change in the constitution of the College. ${ }^{7}$ At its first meeting, held on 16 January 1767, the Society received a note from the Beadle of the College, indicating that the College intended to publish a series of Medical Transactions, and inviting the licentiates to contribute papers. The licentiates refused to do so. Shortly afterwards, they began to collect subscriptions for supporting Dr. Letch's cause. Dr. Fothergill and Dr. William Hunter each gave $£ 500$, and Dr. de la Cour gave $£ 300 .{ }^{8}$ Sir Fletcher Norton, a very eminent barrister, was engaged to represent Dr. Letch, while the College engaged Charles York, perhaps the most brilliant barrister of his day. The issue came to court in May 1767. Norton argued that by his election in the comitia minora Dr. Letch had acquired a right to be a member of the College and that the court should enforce the completion of his right by a mandamus. ${ }^{9}$ Lord Mansfield, however, did not agree, and found for the College. He did, however, intimate to the College a caution against narrowing their grounds of admission so much, that if even a Boerhaave should be resident here he could not be admitted to their fellowship. Two other judges, Yates and Aston, held that Dr. Letch should have applied for a mandamus to make him a licentiate, not to admit him as a member. This raised the question of whether licentiates were members of the College, and the Society of Collegiate Physicians quickly devised a means to test this.

In June 1767 twenty-three licentiates applied in writing to be admitted as fellows, and the College refused their applications. At the quarterly comitia on 25 June, nine licentiates seated themselves among the fellows, and Dr. Silvester, one of the founders of the Society of Collegiate Physicians, began to address the meeting. On being told that he had no right to debate there, he and the other licentiates insisted they had a right to be heard as members of the corporation. At this point the President indicated that unless the licentiates withdrew quietly, he would be obliged to send for constables, whereupon William Hunter declared that if any Man or Constable offered to lay hands upon him to turn him out of their House [adding for this is our House] he would run him through the body'. ${ }^{10}$ Other licentiates agreed to repel force with force. Finding it impossible to transact any business, the President dissolved the comitia.

${ }^{7}$ For a brief history of the Society of Collegiate Physicians, see Lloyd G. Stevenson, 'The siege of Warwick Lane, together with a brief history of the Society of Collegiate Physicians (1767-1798)', J. Hist. Med., 1952, 7, 105-21.

Sir George Clark, A History of the Royal College of Physicians, Oxford, 1966, vol. II, p. 561.

- The litigation is reported in 4 Burr. 2186-2195.

10 From the summary of events prepared by the solicitor of the College for submission to Council, quoted in Stevenson, op. cit., p. 111. The other licentiates, besides Hunter, were Sir William Duncan Thomas Dickson, Alexander Russell, Matthew Maty, Alexander Hay, Sir John Silvester, Michael Morris, and Hugh Alexander Kennedy. 


\section{Waddington}

Another meeting of the comitia was arranged for 24 September. At about the time the meeting was due to commence, a group of twenty-one licentiates, accompanied by a gang of hirelings whom they had engaged in a tavern in St. Paul's Churchyard, arrived at the College gates and demanded to be admitted.11 When they were denied admittance, they broke open the gate and rushed into the courtyard, where they manhandled Mr. Lawrence, the College solicitor, and broke a number of windows. With sledgehammers and crowbars, they then broke open the Hall door, and two other doors leading to the room where the President and fellows were assembled, and sat down amongst them. Once again the President was forced to dissolve the comitia.

More trouble was expected a few days later, for the quarterly meeting of the comitia was due to be held on 30 September. The lock on the gate of the courtyard was specially strengthened, and the College procured a body of constables to repel any invaders. Meanwhile the licentiates met at their usual tavern, where they hired the services of forty ruffians. When they failed, however, to engage a blacksmith, whom they needed to break open the courtyard gate, they decided to drop their plan for another assault on the College, and instead sent a letter to Sir William Browne, the retiring President, demanding admittance to vote in the election of officers of the College. The College sent a written answer, stating that they apprehended the gentlemen who had signed the letter had no right to vote.

After this there was no further violence within the grounds of the College; the 'battle of Warwick Lane', satirized by Samuel Foote in 'The Devil Upon Two Sticks', was over. ${ }^{12}$ The licentiates, however, did not give up their struggle, but switched their attack back to the law courts. Sir Fletcher Norton, again acting on behalf of the licentiates, applied for a writ of quo warranto to be filed against the newly elected censors, to show by what authority they acted as censors. The objection was that they were elected by the fellows only, whereas the election ought to have been by the whole body. Lord Mansfield held the question to be whether the persons applying for the writ were fellows, and entitled to vote in the election of censors. He held that the licence to practise did not amount to an admission into the fellowship of the College. The distinction between fellows and licentiates was, he said, as well known as the distinction between graduates and undergraduates in the universities. Justices Aston, Willes and Yates concurred in this view. ${ }^{18}$ Lord Mansfield, however, repeated his advice to the College to consider reviewing their statutes. He thought there were many licentiates who would do honour to the College, and asked 'how can any byelaws, which exclude the possibility of admitting such persons into the College, stand with the trust reposed in them, of "admitting all that are fit"?' He saw a source of 'great dispute and litigation' in the byelaws as they then stood.

${ }^{11}$ The twenty-one were the above nine, plus [Sir] John Elliot, Charles Morton, Benjamin Alexander, John Brickenden, Maxwell Garthshore, George Fordyce, Hugh Smith, Luke Wayman, David Orme, William Grant, Robert Bromfield, and John Ford.

12 For satirical allusions to the 'battle' in stage plays at the time, see B. C. Corner, 'Dr. Melchisede Broadbrim and the playright', J. Hist. Med., 1952, 7, 122-35. The text of 'The Devil Upon Two Sticks' may be found in the Works of Samuel Foote, London, 1830, vol. III, pp. 5-57.

13 The litigation is reported in 4 Burr. 2195-2204. Willcock disagreed with the view of Lord Mansfield in this case, holding that the byelaws of the College which restricted the fellowship to graduates of Oxford and Cambridge were illegal, because they imposed a qualification not required by the charter and by the act of incorporation. See Willcock's evidence before the Select Committee on Medical Education, 1834, 602-1, part 1, Q.4113-4116. 


\section{The Struggle to Reform the Royal College of Physicians, 1767-1771}

Lord Mansfield's advice was not taken, however, and just over a year later the licentiates brought a third suit against the College. ${ }^{14}$ Sir Fletcher Norton, representing Dr. Edward Archer, a licentiate since 1752, moved for a mandamus to be directed to the College, commanding them to admit him into the 'body and fellowship' of the College. Mr. Walker applied for a similar mandamus on behalf of Dr. John Fothergill. These motions were intended to try the question whether licentiates had a right, not this time to do business, but to be admitted as fellows. In the case of Dr. Archer, it was again held that the licence to practise did not mean that its holder was lawfully entitled to be admitted a member of the College, and the court refused to grant the mandamus applied for. The application on behalf of Fothergill, heard the following year, ${ }^{15}$ was also rejected. Lord Mansfield held that it would be 'a most unreasonable thing ... . to turn this licence so accepted against the persons from whom it was thus accepted and to set it up as the foundation of a right to be admitted under the charter.' At the same time he indicated that he had read all the constitutions, statutes, and byelaws of the College, and found many of them 'narrow, if not illegal'. He concluded by stating that it was now for the College to consider 'whether they will trust to a return upon these byelaws, or mend them.'

After this case, the College finally set about revising the statutes, and before the new statutes were ready it elected three licentiates as fellows, speciali gratia. ${ }^{16}$ Shortly after, two new rules relating to the admission of licentiates into the fellowship were passed. The first of these was that any fellow of the College might propose a licentiate of seven years' standing and not less than thirty-six years of age to be a candidate. He was then to be examined in Greek, in Hippocrates, Galen and Aretaeus, and a number of other subjects. After his examination the fellows were to ballot on his election. The second rule stated that in each year the president might propose one licentiate for election straight away as a fellow. ${ }^{17}$

Miss Hamilton has suggested that these tactics 'succeeded in splitting the ranks of the licentiates, though very few were actually admitted under the byelaws' ${ }^{18}$ Certainly it is true that the byelaws were rarely used to admit licentiates into the fellowship; after the admission of the three licentiates noted above, in 1771 , no more licentiates were admitted until 1784. From this date the new byelaws were used more frequently, and in the period 1784-1790, six licentiates were admitted. ${ }^{19}$ However, in spite of the fact that the new byelaws did little to increase mobility between the two strata, it may still be true that the College succeeded in splitting the ranks of the licentiates. It would seem that without knowledge of how the byelaws were to be applied, the licentiates found it difficult to agree amongst themselves as to how the new rules were going to affect them. Thus, while Fothergill held that they were not upon the whole more liberal than the former, William Watson, another founder member of

14 Rex. v. The College of Physicians, 1769, 5 Burr. 2740-2743.

15 Rex. v. The College of Physicians, 1770, 5 Burr. 2743-2762.

16 The three were Richard Jebb, Donald Munro and James Grieve, all Scottish graduates. A fourth licentiate, Isaac Schomberg, was also admitted into the fellowship at the same time; he, however, held a medical degree from Cambridge, and Munk does not indicate that he was admitted speciali gratia. See Munk's Roll, vol. II, pp. 291-297.

17 Clark, op. cit., vol. II, p. 566.

18 Bernice Hamilton, 'The medical professions in the eighteenth century', Econ. Hist. Rev., 1951, 2nd ser., 4, no. 2, 141-69.

10 Munk's Roll, vol. II. 


\section{Waddington}

the Society of Collegiate Physicians said they were more liberal than he could have expected. 20

What is clear is that after the failure of the suits of Archer and Fothergill and the passing of the new statutes, the Society of Collegiate Physicians became much less militant. From 1771 the Society became less involved with problems of medical reform, and took on more and more the character of a friendly and scientific society. Thus the minute-books of the Society indicate that throughout the 1770 s and 1780 s most of the business of meetings was taken up by dining and listening to reports of cases, medical papers and éloges. ${ }^{21}$ The reconciliation of the Society with the College was complete in 1784. In that year two members of the Society were admitted to the fellowship. The Society promptly responded by passing three important motions. The first stated that every member shall henceforth be at full liberty to contribute to the Transactions of the College if he so wishes. The second motion stated that since the two members who had been created fellows had continued in membership of the Society, in future any fellows of the College might be proposed for membership, and elected by ballot in the usual way. Finally, it was resolved that 'in order further to promote the Union and Harmony of this Society, with the Fellows of the College, the President be from henceforth impowered to invite to Dine at the quarterly meetings of this Society, any number, not exceeding Four at a time, of the Fellows of the Royal College of Physicians'.22

So far we have presented an outline of the development of the struggle between the licentiates and fellows of the College of Physicians; now it is necessary to present a causal analysis of this process. Why was it that from 1767 the licentiates put forward demands for the reform of the College? After all, as Lord Mansfield pointed out, the distinction between fellows and licentiates had been known for upwards of a hundred years. Why then should this distinction, and the privileges associated with it, suddenly become unacceptable? Sir George Clark has suggested that one causally important factor in the development of the struggle was the changing numerical ratio between licentiates and fellows. He argues that 'the numbers of the two grades in the College did not fit in at all conveniently with the distinction of status. If the licentiates had been the rank and file of the profession in London and the fellows a small minority it would have been easier to justify the distinction; but for a long time past there had been fewer licentiates than fellows. In 1708 there were . . . sixty-seven in the upper rank, against thirty-nine licentiates. This disparity was growing worse. In 1746 there were fifty-four fellows and twenty-four licentiates.' ${ }^{23}$ An examination of the numbers of the College, however, would not seem to support Clark's argument. Throughout the first half of the eighteenth century, there were more fellows than licentiates. However, the first year in which the licentiates outnumbered fellowsby 63 to 46-was 1765, just two years before the 'battle of Warwick Lane', and the licentiates continued to outnumber fellows from 1765 onwards. ${ }^{24}$ Thus far from

20 Clark, op. cit., vol. II, p. 566.

21 Stevenson, op. cit., pp. 118-19.

22 Quoted in Stevenson, op. cit., p. 120. These motions were passed in October 1784, but not inserted in the minutes or confirmed until 1786.

sark, op. cit., vol. II, p. 533.

ฯ The numbers of the College are given in Clark, op. cit., vol. II, Appendix II, pp. 736-39. 
being accentuated, the traditional numerical ratio between licentiates and fellows was in fact reversed in the years immediately prior to and during the period when the struggle for reform was most intense.

It is unfortunately the case that while the literature contains many descriptions of the conflict between the licentiates and fellows, no adequate analysis of the social basis of this conflict has yet been put forward. A number of writers have however suggested that the development of the conflict was related in some way to the increased number of graduates of Scottish universities who became licentiates. Thus Miss Franklin has written that 'the struggle of the Licentiates against the Fellows reflected the difference in outlook between the more progressive scientific approach to medicine in the Scottish universities and the traditional classical approach of the English'25 while Sir George Clark has suggested that many licentiates were 'bound together by their Scottish education and several of them also had another link in not being members of the Church of England. ${ }^{26}$ It is the view of the present writer, however, that no analysis has yet brought out the real significance of the Scottish graduates, ${ }^{27}$ and since it will be argued that this group provides a major clue to an understanding of the struggle for reform of the College of Physicians, it is necessary to look at this group in some detail.

INTAKE OF LiCENTIATES ACCORDING to QUALIFICATION, 1726-1775.

(Table compiled from Munk's Roll, Vol. II and the Dictionary of National Biography.)

\begin{tabular}{|c|c|c|c|c|c|c|c|c|}
\hline & Edinburgh & Aberdeen & Glasgow & $\begin{array}{c}\text { St. } \\
\text { Andrew's }\end{array}$ & Oxbridge & Foreign & Unknown & $\begin{array}{c}\text { No } \\
\text { Medical } \\
\text { degree }\end{array}$ \\
\hline $\begin{array}{l}1726-30 \\
1731-35 \\
1736-40 \\
1741-45 \\
1746-50 \\
1751-55 \\
1756-60 \\
1761-65 \\
1766-70 \\
1771-75\end{array}$ & $\begin{array}{l}1 \\
1 \\
1 \\
9 \\
6 \\
2\end{array}$ & $\begin{array}{l}5 \\
4 \\
6 . \\
2\end{array}$ & $\begin{array}{l}1 \\
1\end{array}$ & $\begin{array}{l}1 \\
1 \\
1 \\
3 \\
8\end{array}$ & 2 & $\begin{array}{r}2 \\
1 \\
3 \\
2 \\
2 \\
2 \\
12 \\
3 \\
5 \\
5 \\
6\end{array}$ & 2 & $\begin{array}{l}3 \\
2 \\
2 \\
1 \\
1\end{array}$ \\
\hline
\end{tabular}

Throughout the whole of the first half of the eighteenth century, only seven Scottish graduates were admitted as licentiates of the College. ${ }^{28}$ The largest intake in this period was from graduates of foreign universities, thirty of whom were granted licences to practise. Licences were also granted to nineteen persons who had no medical degree, and to three persons who held a qualification from Cambridge. ${ }^{29}$ From about the middle of the century, however, the pattern of recruitment changed

${ }^{25}$ Franklin, op. cit., p. 1.

26 Clark, op. cit., vol. II, p. 554.

27 The term 'Scottish graduates' is used throughout to refer to graduates of Scottish universities; it does not imply that the graduates themselves were necessarily Scottish, and many of them, in fact, came from England.

${ }_{38}$ This figure, and all the following figures relating to the licentiates have been calculated from Munk's Roll, vol. II.

so That these three Cambridge graduates were not admitted to the fellowship is explained by the fact that two of them held only the M.B. degree, while the third was an alien. The three physicians involved were Thomas Dover, Musshey Teale, and John Scheuchzer (see Munk's Roll, vol. II, pp. 79-81, 82-83, 91-92). 


\section{Waddington}

quite markedly. The numbers of graduates of foreign universities who were admitted increased slightly, while the intake of those holding a degree from the English universities remained at a minimum. The number of persons who were admitted with no medical degree had been falling since the beginning of the century, and continued to decline after 1750 . The major change, however, concerned the intake of Scottish graduates. In the quinquennium 1741-5, two Scottish graduates were admitted; in 1746-50 only one. From 1750 the numbers increased rapidly. In the period 1751-5, seven were admitted, in 1756-60, eleven, and in 1761-5, no less than twenty-five. The changing pattern of recruitment is clearly illustrated in the following table, which gives a complete breakdown of admissions, by education, in the fifty year period 1726-75.

These figures reflect quite clearly the rise of the Scottish medical schools in the eighteenth century, of which more will be said later, and indicate that in the years immediately preceding the conflict between the licentiates and fellows, a rapidly increasing number of Scottish graduates were admitted as licentiates. It is perhaps important to add, since the above table does not give figures for individual years, that of the twenty-five Scottish graduates admitted between 1761-65, seventeen were admitted in 1765, just two years before the conflict in the College flared up. Moreover, there is some evidence to suggest that the Scottish graduates played an active part in the struggle of the licentiates. Thus the first meeting of the Society of Collegiate Physicians was attended by thirty-one licentiates, of whom twenty-one were Scottish graduates. At this meeting, a president, a treasurer, two stewards and a secretary were elected; four of the five offices, including that of president, were filled by graduates of Scottish universities..$^{30}$ The Scottish graduates were also well represented in the violent assault on the College in May 1767. Of the twenty-one licentiates who took part, fourteen were graduates of Scottish universities, and at least one other had attended courses at Edinburgh. The strength of the Scottisheducated contigent is also indicated in contemporary illustrations of the siege of the College. One of these shows the licentiates carrying two banners, one of which bears the inscription 'Pro Collegiis Scotiae', and the other 'Delenda Est Oxonia Delenda Est Cantabria'. In another illustration, the Scottish influence is clearly represented by the dress of the licentiates, while the fellows are pictured with words put into their mouths, indicating their anti-Scottish sentiments. ${ }^{31}$

There is thus some evidence to indicate that the development of the conflict within the College of Physicians was related to the changing number of Scottish graduates who were admitted as licentiates, and that those who had received their professional education in Scotland were among the most militant of the licentiates. Now why did the Scottish graduates play such an active part in the struggle for the reform of the College of Physicians? Why were they so dissatisfied with the traditional structure of the College? In order to answer this, it is necessary to examine briefly the structure of medical practice in Scotland, and the development of the Scottish medical schools.

In Scotland, the separation between medicine and surgery had never been as rigid as it was in England. In Glasgow, practitioners of medicine and surgery had been

20 Stevenson, op. cit., p. 110.

31 Both illustrations are reproduced in Stevenson, op. cit. 


\section{The Struggle to Reform the Royal College of Physicians, 1767-1771}

united in the Faculty of Physicians and Surgeons since its foundation in $1599 .{ }^{32}$ Many practitioners had thus long united the practice of medicine with that of surgery, ${ }^{33}$ and this rapprochement between the different branches of practice was carried a step further with the development of the medical schools at Edinburgh and Glasgow. At Edinburgh, extra-mural teaching had been carried on, in one form or another, since the early sixteenth century, but it was not until 1726 that a medical faculty was established in the university. In 1720, Alexander Monro primus, who had been a favourite pupil of Boerhaave at Leyden, was appointed professor of anatomy, and he began teaching in the same year. Six years later, the Town Council, which had long been the governing body of the university, appointed Andrew Sinclair and John Rutherford as professors of the theory and practice of medicine, and Andrew Plummer and John Innes as professors of medicine and chemistry. They were given 'full power ... to profess and teach Medicine in all its branches-to examine candidates, and to do every other thing requisite and necessary to the graduation of doctors of medicine.' ${ }^{34}$ From this time onwards, all the professors delivered regular and systematic courses of instruction. Monro taught anatomy and surgery, while Innes taught the practice of physic conjointly with Rutherford. Plummer lectured on chemistry as applied to pharmacy, and Sinclair took the institutes of theory of medicine as his province, using Boerhaave's Institutiones Medicae as his text book. ${ }^{35}$

In 1726 the Town Council also created a chair of midwifery, not, however, for the university, but for the city. Thus the first holder of the chair, Joseph Gibson, was not a member of the medical faculty in the university. On the death of Gibson in 1739 however, his successor, Robert Smith, was appointed professor of midwifery in the university, 'with the same privileges and immunities' as the other professors. ${ }^{36}$ One other chair was created within the faculty in the first half of the eighteenth century, that of medicine and botany, in 1738. Charles Alston was appointed to the chair, and he delivered two courses of lectures annually for the next twenty-two yearsone on botany and one on materia medica. ${ }^{37}$

Medical students at the university were given clinical instruction from 1729 , when a small infirmary was opened in the city. By the following year this instruction had proved so popular that the managers of the hospital drew up rules governing the conduct of clinical instruction and introduced a fee for 'walking the wards'. Soon, however, the facilities at the hospital proved inadequate, and a new, much larger hospital, designated by Royal Charter as the Royal Infirmary, was opened in $1741 .^{38}$

Edinburgh quickly gained an excellent reputation for the quality of its teaching, and by the middle of the eighteenth century it was rivalling Leyden for the position of Europe's leading medical school. Edinburgh, however, did not simply offer a

32 The jurisdiction of the Faculty was not limited to the city of Glasgow, but extended to the baronies of Glasgow, Renfrew, and Dumbarton, and to the sheriffdoms of Clydesdale, Renfrew, Lanark, Kyle, Carrick, Ayr and Cunningham.

K. Pollack and E. A. Underwood, The Healers, London, 1968, p. 117.

" Sir Alexander Grant, The Story of the University of Edinburgh, 2 vols., London, 1884, vol. 1, p. 313.

ss Ibid., vol. I, p. 315.

s" Ibid., vol. I, pp. 315-16.

87 Ibid., vol. I, p. 318.

${ }^{28}$ H. P. Tait, 'Medical education at the Scottish Universities to the close of the eighteenth century', in F. N. L. Poynter (ed.), The Evolution of Medical Education in Britain, London, 1966, pp. 63-64. 


\section{Waddington}

good medical education; it offered a medical education of a type quite new in Britain, involving the integration of a wide range of medical and allied subjects. By 1739, students at Edinburgh were given instruction not only in all the main branches of medicine, but also in anatomy and surgery, botany, chemistry as applied to pharmacy, and midwifery. Nothing like such a comprehensive education was available in England, where the education and examination of intending practitioners continued to be organized in terms of the traditional tripartite structure of the profession.

Thus in England the education of physicians was quite different from that of surgeons and apothecaries. The English universities aimed to produce cultured physicians, and it was not expected that such gentlemen, educated in the classics, would have much knowledge of the manual skills involved in such things as surgery, midwifery or the preparation of drugs. The examination for the licence of the College of Physicians involved only a narrow range of subjects, the College declining to examine in those branches of practice traditionally held to be outside the province of the physician. ${ }^{39}$ Surgeons and apothecaries, as befitted those who practised a craft or trade, usually received their training by apprenticeship. Like physicians, however, neither surgeons nor apothecaries were required to undergo an examination in all branches of practice. Thus candidates for the diploma of the Company of Surgeons were not examined in medicine or pharmacy, while surgery was not included in the examination of the Society of Apothecaries.

The development of the Edinburgh medical school was thus of considerable importance, for by integrating the teaching of medicine, surgery, and allied subjects, Edinburgh became the first medical school in Britain to provide an education designed to fit medical students to become general practitioners.

The medical school at Glasgow University developed a little later than that at Edinburgh. In 1742 Robert Hamilton was appointed to the chair of anatomy, and he appears to have taught the subject quite creditably. Four years later, William Cullen, after a short period as a private teacher, began lecturing on medicine within the university, and in 1748 he added lectures on materia medica and botany. He was appointed to the chair of medicine in 1750 , about which time John Carrick, who had formerly aided Cullen in his courses on botany and materia medica, began lecturing on chemistry. Surgery was taught by the professor of anatomy, as it continued to be until 1815. At the Glasgow medical school, as at that of Edinburgh, no rigid distinctions were drawn between different branches of practice, and by the middle of the eighteenth century, students at Glasgow were given instruction in both medicine and surgery, and in those subjects which formed the basis of pharmacy. ${ }^{10}$ Thus Glasgow, like Edinburgh, offered what was essentially an education for general practice.

In addition to Edinburgh and Glasgow, three other bodies in Scotland awarded degrees in medicine - the University of St. Andrews, and the two colleges in Aberdeen, King's and Marischal. At none of these institutions, however, was there any systematic teaching of medicine in the eighteenth century, and all three conferred degrees

30 As late as 1834, surgery and midwifery were still excluded from the examinations of the College. See the Select Committee on Medical Education, 1834, 602-1, part 1, Q.2025-2027, 2568.

${ }^{\star 0}$ For the early development of the Glasgow medical school, see James Coutts, A History of the University of Glasgow, Glasgow, 1909, pp. 476-512. 


\section{The Struggle to Reform the Royal College of Physicians, 1767-1771}

without requiring any residence, without requiring candidates to have undergone any particular course of study, and, not infrequently, without even subjecting candidates to an examination. At St. Andrews, medical degrees were often conferred in absentia, in return for payment, the fee in 1747 being $£ 10$, of which the professor of medicine received $£ 3 .{ }^{41}$ The ease with which medical degrees could be obtained from these institutions was satirized in Samuel Foote's play 'The Devil Upon Two Sticks'. Last, one of the characters in the play, explains that he has been in practice, without a licence, for about twelve years, but that now Lotion, a local apothecary who has 'grown old and lascivious' threatens to report him if he continues to practise without a qualification. Last goes on to say that 'I was telling my tale to Sawney McGregor, who comes now and then to our town with his pack; God, he advised me to get made a doctor at once, and send for a diplummy from Scotland'.42 In spite of the lax manner in which degrees were granted, however, there is little reason to believe that graduates of St. Andrews or of either of the Aberdeen colleges were generally ignorant of their profession. In 1774, in a letter to William Cullen, who was then President of the Royal College of Physicians of Edinburgh, Adam Smith outlined his views on the conditions of graduation at Aberdeen and St. Andrews. While he criticized these institutions for taking part in what he called 'a most disgraceful trade' in degrees, Smith held that this practice rarely resulted in harm to the public. The title of Doctor, he held, 'is not so very imposing, and it very seldom happens that a man trusts his health to another merely because that other is a doctor. The person so trusted has almost always either some knowledge or some craft which would procure him nearly the same trust, though he was not decorated with any such title. In fact, the persons who apply for degrees in the irregular manner complained of, are, the greater part of them, surgeons or apothecaries, who are in the custom of advising and prescribing, that is, of practising as physicians; but who, being only surgeons and apothecaries, are not feed as physicians. It is not so much to extend their practice as to increase their fees that they are desirous of being made doctors.' 43

Smith thus suggests that many of those who graduated from St. Andrews and Aberdeen were either apothecaries or surgeons who were practising generally. This is very probable; an examination of Munk's Roll indicates that it was quite common for practitioners who were educated as surgeons and/or apothecaries, and who practised as such, to obtain a medical degree from one or other of these institutions. Thus Munk tells us that Joseph Allen was 'bred a surgeon' in which capacity he accompanied Lord Anson on his voyage around the world. He obtained a medical

41 J. D. Comrie, History of Scottish Medicine, 2 vols., London, 1932, vol. II, p. 575.

12 Foote's Works, op. cit., vol. III, p. 36.

13 The letter, dated 20 September 1774, is to be found in The Wealth of Nations, ed. by J. R. McCulloch, 1838, note XX, pp. 582-85. Comrie has noted that at Marischal College, Aberdeen, 'for many years those who graduated appear to have been men who had already been for a considerable time in practice or who had published works on medicine', while at King's College, degrees in medicine were conferred 'not because of examinations which the student had successfully passed, but as a recognition by the university of general and professional attainments, however acquired.' He cites as an example of the manner in which degrees were given for purely honorary reasons and in absentia, the case of Patrick Blair, an apothecary in Cupar, who graduated M.D. from King's College in 1712 after being recommended by the Bishop of Aberdeen and several eminent physicians in Angus (Comrie, op. cit., vol. I, pp. 369-70). This is in accordance with Smith's observations. 


\section{Waddington}

degree from St. Andrews in 1754.44 John Fordyce, who practised for several years as a surgeon-apothecary at Uppingham, obtained a medical degree from Marischal College in $1756 .{ }^{45}$ Edward Spry served a five-year apprenticeship to a practitioner in Plymouth, and after continuing his education in London and on the continent, he returned to Plymouth and commenced practice as a surgeon. He was created Doctor of Medicine by the University of Aberdeen in 1759.46 The career of Thomas Denman was a little more varied. He was the second son of an apothecary, and on the death of his father he assisted his elder brother, who succeeded to the business. After attending classes in London he was appointed as a surgeon's mate in the navy, and in 1757 he was made surgeon. He left the service in 1763 and attended Dr. Smellie's lectures on midwifery, and the following year was created Doctor of Medicine by Aberdeen University. He subsequently became surgeon to one of the royal yachts, and developed a lucrative practice as an accoucheur. ${ }^{47}$ Other examples may be readily found in the pages of Munk's Roll. ${ }^{48}$

It should be pointed out, however, that the granting of medical degrees to persons who had been in practice as surgeons or apothecaries was not confined to St. Andrews and Aberdeen, for it was also quite common at Edinburgh and Glasgow. Thus all the Scottish universities included among their graduates a considerable number of persons who had had experience in one or other of the lower branches of the profession. ${ }^{49}$ From this it may be argued that the Scottish universities functioned as important channels of social mobility, by providing many surgeons and apothecaries with the opportunity of improving the status of their practices, and, as Smith noted, of raising their fees.

It is significant that while it was common for surgeons or apothecaries to obtain a degree from one of the Scottish universities, this was virtually unknown at Oxford and Cambridge; almost invariably, graduates of the latter began their professional careers as physicians. Thus the career structure of many Scottish graduates was quite different from that of physicians educated at the English universities.

The preceding analysis is of some importance for an understanding of the struggle for the reform of the College of Physicians, for as we have seen, in the years immediately prior to the attempts to reform the College, there was a rapid increase in the number of Scottish graduates who became licentiates; we have also seen that the Scottish graduates played a very active part in the struggle for reform. Why, then, was the influx of Scottish graduates so significant? In the analysis so far it has been argued that the structure of medical practice and medical education in Scotland had

"14 Munk's Roll, vol. II, p. 272.

45 Ibid., vol. II, p. 212.

46 Ibid., vol. II, p. 281-83.

17 Ibid., vol. II, pp. 333-34.

18 See, for example, the biographical sketches in Munk's Roll of William Baylies, Thomas Dimsdale, Michael Underwood and William Rowsley (vol. II, pp. 232-33, 271, 336-37, 340). A more famous example is that of Tobias Smollett, the novelist, who graduated M.D. from Marischal College, Aberdeen, in 1750; prior to this he had been a surgeon's mate in the navy, and in 1744 had commenced practice as a surgeon from a house in Downing Street. See David Hannay, Life of Tobias George Smollett, London, 1887, pp. 28, 42, 111 .

40 Lester King has noted that many Scottish graduates had taken 'a certain amount of apprenticeship with an apothecary or surgeon', and adds, also in relation to the Scottish universities, that many individuals 'started their professional careers as apothecaries but finally achieved a doctor's degree'. See L. S. King, The Medical World of the Eighteenth Century, Chicago, 1958, pp. 27-28. 
The Struggle to Reform the Royal College of Physicians, 1767-1771

certain distinctive features. Firstly, it was pointed out that in Scotland the general practitioner had long been the rule. Secondly, it was argued that the two universities which offered any systematic instruction in medicine, namely Edinburgh and Glasgow, both aimed at integrating all the major branches of practice, and thus offered what was essentially an education for general practice. Finally, it was pointed out that all the Scottish universities frequently granted medical degrees to persons who had been in practice as surgeons or apothecaries. It is suggested that, with their distinctive educational and professional experiences, Scottish graduates would be much less likely to confine their practice to pure medicine than would those who had received their professional education outside Scotland.

The examination of the structure of medical education and medical practice in Scotland suggests therefore, the probability that many of the Scottish-educated licentiates did not practise as pure physicians. More direct evidence to support this suggestion may be found in Munk's biographical sketches of many of those who took a leading part in the struggle for reform. Perhaps the most famous of the rebel licentiates was William Hunter, who was one of the stewards of the Society of Collegiate Physicians. Hunter received his early medical education from Dr. Cullen, with whom he resided at Hamilton for three years, and in 1741 came to London, where he lived with Mr. (later Dr.) Smellie, at that time an apothecary in Pall Mall. Later he entered as a surgeon's pupil at St. George's Hospital, and in 1747 obtained the diploma of the Corporation of Surgeons. Hunter practised both surgery and midwifery, but had a marked preference for the latter. He graduated from Glasgow in 1750, but his major interests remained in the fields of anatomy and obstetrics, and throughout the third quarter of the eighteenth century he was the most eminent accoucheur in London. ${ }^{50}$

Many of the other Scottish graduates who were active in the struggle for the reform of the College had, like Hunter, been educated as surgeons or apothecaries. Thus Maxwell Garthshore served an apprenticeship to a surgeon-apothecary in Edinburgh, on completion of which he became a surgeon's mate in the army. In 1756 he settled at Uppingham, taking over the lucrative practice which John Fordyce had built up as a surgeon-apothecary, and which the latter relinquished on moving to London. In 1764, Garthshore graduated from Edinburgh and, moving to London, was admitted a licentiate of the College in the same year. In London he practised chiefly as an accoucheur. $^{51}$ John Fothergill, the other steward of the Society of Collegiate Physicians, was 'bred an apothecary' and served an apprenticeship to Benjamin Bartlett, an apothecary at Bradfield in Yorkshire. ${ }^{52}$ Luke Wayman was also 'bred an apothecary', in which capacity he practised at Royston for several years, ${ }^{53}$ while John Elliot began his medical career as an apothecary's assistant, and later went to sea as a surgeon. ${ }^{54}$

An examination of Munk's Roll and the Dictionary of National Biography indicates

so Munk's Roll, vol. II, pp. 205-11. See also Dictionary of National Biography, 'William Hunter'; and Jane Oppenheimer 'William Hunter and his contemporaries', in J. M. Oppenheimer, New Aspects of John and William Hunter, London, 1946.

61 Munk's Roll, vol. II, p. 259. See also Gentleman's Magazine, 1812, 387-91.

${ }^{52}$ Munk's Roll, vol. II, p. 154.

ss Ibid., vol. II, p. 268.

s4 Ibid., vol. II, p. 239. 


\section{Waddington}

that, of the twenty-one Scottish graduates who attended the first meeting of the Society of Collegiate Physicians, no less than nine had been educated as surgeons or apothecaries, while a tenth, Hugh Smith, was the son of a surgeon-apothecary, and probably received some instruction from his father. In fact, however, the number of Scottish graduates who were trained as surgeons or apothecaries may well have been higher. The main source for biographies of the licentiates is Munk's Roll, and it is clear that this information is far from complete. Thus Munk indicates that Alexander Russell 'studied medicine under his uncle, an eminent practitioner in Edinburgh'; he does not indicate, however, that the uncle in question was a surgeon. Similarly, in his note on John Hill, Munk does not indicate that Hill began his medical career as an apothecary. In the cases of Russell and Hill, fuller details of their careers were obtained by cross-checking Munk's biographies with those in the Dictionary of National Biography. Since, however, many of the licentiates who took part in the struggle for reform are not listed in the latter, it has not always been possible to check Munk's information.

In addition to these Scottish graduates who had been educated as surgeons or apothecaries, a number are known to have practised midwifery. Indeed, it would seem that this practice was common among Scottish graduates, as indicated by William Hunter's famous toast 'May no English nobleman venture out of the world without a Scottish physician, as I am sure there are none who venture in. ${ }^{55}$

To summarize, of the Scottish graduates who were active in the Society of Collegiate Physicians, something like a half had received their professional training at Edinburgh, probably the finest school for general practitioners in Europe. Just under a half had originally been trained as surgeons or apothecaries, and, in addition, there is some reason to believe that the practice of midwifery was common among Scottish graduates. All this tends to support the suggestion that many Scottish graduates did not practise as pure physicians. This is of major importance, for the struggle to reform the College of Physicians has traditionally been regarded as a conflict between two groups of physicians, the fellows and the licentiates It is suggested here, however, that the structural basis of the conflict lay in the fact that the Scottish graduates did not practise as physicians, but as general practitioners. In order to understand this fully, we have to examine briefly the structure of the College of Physicians, and the policies pursued by the College.

Traditionally, the physician was, as we have seen, a cultured gentleman, learned in the classics. He was not expected to have much knowledge of the manual skills involved in the work of the surgeon or apothecary and indeed, as is common among privileged status groups, ${ }^{56}$ such work was shunned as degrading. The prejudice against manual work was, in fact, the central aspect of a complex ethos which

ss Quoted in Oppenheimer, op. cit., pp. 124-25.

se. From Max Weber, Essays in Sociology, trans. and ed. by H. H. Gerth and C. W. Mills, London, 1961 , p. 191. The idea that it was degrading for a gentleman to engage in manual work persisted well into the nineteenth century. In Trollope's Doctor Thorne, first published in 1858, we read that, to the physicians of Barchester, it was clear that Dr. Thorne 'had no appreciation of the dignity of a learned profession. He might constantly be seen compounding medicines in the shop, at the left hand of his front door; not making experiments philosophically, in materia medica for the benefit of coming ages-which, if he did, he should have done in the seclusion of his study, far from profane eyes-but positively putting together common powders for rural bowels, or spreading vulgar ointments for agricultural ailments.' (Anthony Trollope, Dr. Thorne, Everyman's Library, 1967, p. 26). 


\section{The Struggle to Reform the Royal College of Physicians, 1767-1771}

physicians had developed as a legitimation of their dominant position within the profession, and of their high status within the wider community. Another important aspect of this ethos involved the rejection of participation in any overtly economic activities. As Max Weber has pointed out, 'the notion of honour peculiar to status absolutely abhors that which is essential to the market: higgling. . . . Therefore, everywhere some status groups, and usually the most influential, consider almost any kind of overt participation in economic acquisition as absolutely stigmatizing. ${ }^{\mathbf{5 7}}$ Within the medical profession there was, on this point, a clear contrast, enshrined in law, between physicians on the one hand, and surgeons and apothecaries on the other. Thus while surgeons and apothecaries could sue a patient for recovery of charges, physicians were unable, prior to the Medical Act of 1858 , to bring such an action. As befitted gentlemen, physicians were considered, so far as the law was concerned, as attending patients for an honorarium, and as such, they were unable to maintain an action for fees. ${ }^{58}$

In order to maintain the high status which physicians had long enjoyed, the College of Physicians persistently attempted to maintain the barrier between the physician and the 'lower orders' of surgeons and apothecaries, who were regarded as craftsmen or traders rather than gentlemen. Thus, as we have seen, the College refused to examine candidates for its licence in any branches of practice traditionally held to be outside the sphere of the physician. Moreover, the College, like the Company of Surgeons, who were equally keen to draw a sharp line between themselves and the mere apothecaries, excluded from its governing Council those who practised as apothecaries, and those who practised midwifery. The means by which the two corporations had effected this policy were however different. In the Company of Surgeons, a bye-law of 7 April 1748 expressly stated that no persons following 'any other trade or occupation besides the profession or business of a surgeon' could be chosen into the Court of Assistants (Council)'. ${ }^{59}$ In the College of Physicians, however, the policy of excluding from the Council those who worked with their hands had, for a long time, been achieved by restricting the fellowship of the College to graduates of Oxford or Cambridge, that is, to gentlemen by whom the manual work involved

${ }^{57}$ Gerth and Mills, op. cit., p. 193.

${ }^{88}$ Poucher v. Norman, 3 B. and C.744, and Chorley v. Balcot, 4 T.R. 317. This difference in the legal status of different types of practitioners with regard to recovery of charges may seem trivial to the modern reader, but it was clearly regarded by physicians as being of considerable importance until well into the nineteenth century. As late as 1847, J. A. Paris, the President of the Royal College of Physicians objected to a medical reform bill which had been introduced into the House of Commons, partly on the ground that it would give physicians the right of recovering payment of charges for their attendance. Paris said 'We object to that very much; we consider that the physician would under these clauses be converted into a tradesman; we should feel that we had lost caste by allowing those clauses to pass.' See the Select Committee on Medical Registration, 1847, (620), Q.104. Note also, in Trollope's Dr. Thorne, that the physicians of Barchester and Silverbridge held that Thorne 'was always thinking of his money, like an apothecary, as he was; whereas, it would have behoved him, as a physician ...., to have regarded his own pursuits in a purely philosophical spirit, and to have taken any gain which might have accrued as an accidental adjunct to his station in life. A physician should take his fee without letting his left hand know what his right hand was doing; It should be taken without a thought, without a look, without a move of the facial muscles; the true physician should hardly be aware that the last friendly grasp of the hand had been made more precious by the touch of gold. Whereas, that fellow Thorne would lug out half-a-crown from his breeches pocket and give it in change for a ten-shilling piece.' (See Trollope, op. cit., p. 26.)

${ }^{50}$ First and second reports from the Select Committee on Medical Registration and Medical Law Amendment, 1847-48 (210), Q.11. 


\section{Waddington}

in pharmacy or midwifery was seen as degrading. When, however, the influx of a large number of Scottish-educated general practitioners posed a major threat to the traditional ideal of the gentleman-physician, the College quickly responded by making the ban on the practice of midwifery and pharmacy explicit. Thus in 1771, new byelaws were passed which stated that no person practising midwifery was to be admitted to the fellowship, that physicians practising as apothecaries were not to be admitted, and that fellows who entered on practice as apothecaries were to be expelled. ${ }^{60}$ Thereafter the College fought a long battle against the rise of the general practitioner, and the dilution of the gentleman-physician ideal which this implied. In 1795 the College approved the refusal of the President, Sir George Baker, to examine an apothecary who applied for a licence to practise as a physician, and instructed the officers of the College to prepare a statute authorizing the like rejection of any person employed as an apothecary or surgeon. ${ }^{61}$ In the 1820 s, after a suggestion that the College should examine in midwifery, a committee reported to the College, giving a plethora of historical information, tending to show that 'the object of the College has been to confine the fellows to the pure practice of physic.' ${ }^{62}$ In 1834, it was still necessary for an apothecary or surgeon to be disfranchised from the Society of Apothecaries or the College of Surgeons before applying for a licence from the College of Physicians. ${ }^{\text {B3 }}$

It should be apparent that the Scottish-educated general practitioners did not fit in neatly with the traditional ideal of the gentleman-physician, and it is hardly surprising that they should be dissatisfied with a College which was dedicated to maintaining the separation between medicine and other branches of practice. It must be emphasized that the problem of the relationship between medicine, surgery, pharmacy, and midwifery was not simply an abstract debate about the nature of medicine as a body of knowledge, for, as has been pointed out, the whole problem was intimately bound up with questions of status, both within the professional community, and in the wider society. It would be very wrong, therefore, to regard the conflict between the licentiates and fellows as simply a conflict on the level of ideas about the relative merits or demerits of 'scientific' Scottish medicine as opposed to the more classically oriented English medicine, for there was a very real conflict of interests on a social structural level.

This conflict can perhaps best be understood in terms of Elias and Scotson's conceptualization of 'established' and 'outsider' groups. ${ }^{64}$ The pure physicians constituted an old, established group par excellence. Long regarded as the dominant group within the profession, their position of dominance, and their high status in the wider society, rested essentially on their claim to be gentlemen. It was, however, precisely this claim which the Scottish-educated licentiates, by engaging in work normally performed by surgeons and apothecaries, threatened to undermine. The pure physicians feared that the influx of general practitioners would drag them down to a lower status level in their own estimation as well as in that of the profession and

${ }^{60}$ Clark, op. cit., vol. II, p. 566.

01 Ibid., vol. II, p. 621.

'2 Ibid., vol. II, p. 664.

os Select Committee on Medical Education, 1834, (602-1), part 1, Q.1814 2739, 3464-3465.

${ }^{64} \mathrm{~N}$. Elias and J. L. Scotson, The Established and the Outsiders, London, 1965. 
The Struggle to Reform the Royal College of Physicians, 1767-1771

the wider society. In the face of this threat, the fellows reacted in a manner typical of the way in which established groups generally react to such threats to their status. Thus, while they could not prevent the Scottish universities from producing large numbers of general practitioners, they could, and did, draw a sharp line between themselves and the general practitioners, relegating the latter to an unambiguously subordinate position within the profession. Thus not only was the licentiates' characteristic mode of earning a livelihood-general practice-clearly defined as a lower status occupation, but the general practitioners themselves were excluded from holding political offices within the College, first by the rule which restricted the fellowship to graduates of Oxford and Cambridge, and subsequently by the bye-laws of 1771.

Given this situation, it is hardly surprising that the Scottish graduates should be dissatisfied with the traditional structure of the College, for the Scottish-educated licentiates were, in effect, general practitioners within a College of Physicians whose policies were designed precisely to prevent the rise of the general practitioner. It should be emphasized that while the institutional structure of the profession was organized around the traditional structure of physicians, surgeons, and apothecaries, the general practitioner was neither physician, nor surgeon, nor apothecary; he was essentially a new type of practitioner, standing outside of this traditional structure. As such, there was no clearly defined position for him within this structure. Unwanted by all the medical corporations, the general practitioner was at best tolerated, never welcomed as a full member of the professional community.

The relationship between 'established' and 'outsider' groups, of which it is suggested that this is an example, has been summarized, in a different context, by Elias and Scotson as follows: 'The newcomers resent, and often try to rise from, the inferior status attributed to them and the established try to preserve their superior status which the newcomers appear to threaten. The newcomers cast in the role of outsiders are perceived by the established as people "who do not know their place"; they offend the sensibilities of the established by behaving in a manner which bears in their eyes clearly the stigma of social inferiority, and yet, in many cases, newcomer groups quite innocently are apt to behave, at least for a time, as if they were the equals of their new neighbours.' ${ }^{\prime} 5$ The basic problem which confronted the medical profession for over a hundred years from the mid-eighteenth century onwards, was of how to integrate this new type of practitioner, the general practitioner into an established institutional structure which had no place for him. It is suggested that the movement to reform the College of Physicians in the period 1767-71 can properly be seen as the first of a long series of movements by general practitioners to achieve a recognized and respectable position within the profession.

Perhaps it is necessary to point out that, while it is clear that most Scottish graduates were practising generally, it is not suggested that, as yet, they had any clear-cut conception of themselves as general practitioners. Rather, it would seem that they continued, at this stage, to see themselves as physicians; that this was so is indicated by the nature of their demands. Thus what the licentiates demanded was essentially recognition of their status, not as general practitioners, but as full members of the

es Ibid., p. 158. 


\section{Waddington}

College of Physicians. In medicine, as in other fields, changes in terminology and in men's self-conceptions occurred somewhat more slowly than changes in the actual structure of the profession. Thus whereas the general practitioner emerged in the eighteenth century, the term 'general practitioner' did not emerge until the early nineteenth century. ${ }^{66}$ The development of what may be called a 'general practitioner consciousness' was thus a product of the nineteenth, rather than of the eighteenth century.

It has been suggested that the most important causal factor in the development of the reform movement within the College of Physicians was the emergence of a new type of medical practitioner alongside an established institutional structure which had no place for him. Nevertheless, in seeking for an adequate analysis of this movement, it would be wrong to ignore completely changes occurring outside the profession. In particular this movement may be related to changes in the structure of political activity on a national level.

The period from 1760 onwards was one of considerable dissatisfaction with the structure of English politics. The parliamentary system came to be increasingly criticized, both for its widespread corruption, and for its unrepresentative character. As E. Neville Williams has pointed out, 'the whole eighteenth century system was subjected to searching criticism, not merely of its practical working but even of its theoretical foundations. ${ }^{\prime} 7$ The extent of the discontent with the political system is indicated not only by the 'Wilkes and Liberty' movement of 1768-69, but also by the development of a number of other reform movements, including the Society of Supporters of the Bill of Rights, founded by Wilkes' ally, 'Parson' John Horne, and by the widespread circulation of a number of radical political tracts. In 1772-3, James Burgh in his enormously popular Political Disquisitions, demanded universal male suffrage, a principle which Wilkes introduced into his measure for parliamentary reform, rejected by the Commons in 1776. That year also saw the publication of Major Cartwright's Take Your Choice! and of Richard Price's On Civil Liberty, the latter of which sold 60,000 copies immediately and double that number in a cheaper edition. ${ }^{68}$

It is not the task of this paper to examine this movement in any detail. It is, however, important to note the similarity between the objectives of the licentiates of the College of Physicians, and of those demanding political reforms on a national level. In a long-term perspective, the significance of this wider reform movement of the eighteenth century lies in the important part which it played in the extension to all members of the community of what T. H. Marshall has called citizenship rights. ${ }^{69}$ The claim to be admitted to citizenship is, as Marshall has pointed out, 'a claim to be admitted to a share in the social heritage, which in turn means a claim to be accepted as full members of the society'. The notion of citizenship involves, above all else, the idea

68 W. J. Bishop, 'The evolution of the general practitioner in England', in E. Ashworth Underwood (ed.), Science, Medicine and History, Essays in Honour of Charles Singer, Oxford, 1953, vol. II, p. 355.

'E. N. Williams, The Eighteenth-Century Constitution, 1688-1815, Documents and Commentary, Cambridge, 1960, p. 208.

${ }^{68}$ For a brief outline of the reform movement, see J. H. Plumb, England in the Eighteenth Century, Penguin Books, 1969, pp. 133-40.

60 'Citizenship and social class' in T. H. Marshall, Sociology at the Crossroads and other Essays, London, 1963. 
that there is 'a kind of basic human equality associated with the concept of full membership of a community'. ${ }^{70}$ It was this basic aim-full membership of their respective communities-which the licentiates shared with the radicals in the wider society, for essentially the licentiates were demanding full membership of their professional community, just as the radicals demanded full membership of the political community.

Finally, one other important similarity between these movements should be brought out. As Professor Rudé has pointed out, pre-industrial popular movements had certain distinctive characteristics which enables them to be differentiated from the earlier popular movements of the medieval period on the one hand, and from the later 'industrial' movements on the other. ${ }^{71}$ It is significant that the movement to reform the College of Physicians, like other popular protest movements of the period, was in many respects characteristically pre-industrial in form. This is particularly true of the licentiates' violent assault on the College in 1767, which exhibited many of the structural characteristics typical of what Rudé has called the " "pre-industrial" crowd'. Those aspects of the violent assault on the College which mark it as a "preindustrial' form of protest include what Rudé terms its 'form of action', its 'spontaneity' and lack of organization, and, on the level of ideology, its concern for tradition and for the restoration of 'lost' rights. ${ }^{72}$ The 'forms of action' typical of the 'preindustrial crowd' were predominantly of the 'direct-action' type. The prevailing form of protest was one of violence applied to property, but not to life and limb.

In the assault on the College on 24 September 1767, the licentiates broke forty windows and smashed three doors. The tactics were clearly those of the eighteenthcentury 'mob', even though the participants were of a higher social status. The 'spontaneity' and lack of organization is also indicated by the events of 24 September and 30 September 1767, for on both occasions the plan to assault the College was probably conceived immediately beforehand in the tavern in St. Paul's Churchyard. A particularly clear indication of the spontaneity of these tactics is to be seen in the licentiates' failure, on 30 September, to engage a blacksmith, whom they needed to break open the College gates. Clearly no blacksmith had been hired in advance, and when the licentiates failed to hire one in the tavern, they had to change their plan of action.

Of even greater importance, however, was the licentiates' concern with tradition and with the restoration of 'lost' rights, for this characterized the whole movement from 1767-1771. Their campaign, in fact, revolved around the idea that at some point in the development of the College, the fellows had illegally usurped the control of the College, thus deviating from the College's assumed original egalitarian structure. In addition, as we have seen, the licentiates conceived of themselves not in their new role of general practitioners, but in the traditional role of physicians. As such, their campaign was essentially backward-looking and conservative, for what the general practitioner licentiates were demanding was, in effect, assimilation into the traditional institutional structure of the profession. The general practitioner, however, by the ${ }^{70}$ Ibid., p. 72.

71 See the essay entitled 'The "pre-industrial" crowd', in George Rude, Paris and London in the Eighteenth Century: Studies in Popular Protest, London, 1970.

72 Ibid., pp. 19-23. 


\section{Waddington}

very nature of his type of practice, cut across all the traditional professional boundaries in terms of which this institutional structure had been established, and there could, therefore, be no possibility of general practitioners achieving a recognized position within the profession as long as this traditional institutional structure remained unchanged. The future of the general practitioner was to lie not in backward-looking aims, such as those which characterized the licentiates' movement, but in the development of new institutions which more adequately represented his interests, and, eventually, in the abolition of the traditional tripartite structure of the profession.

\section{ACKNOWLEDGEMENTS}

The author wishes to thank Professor I. Neustadt, Mr. S. W. F. Holloway, and Mr. N. Jewson, of the Department of Sociology, University of Leicester, for their comments on an earlier draft of this paper. 